\title{
Analisis Optimalisasi Pengelolaan Aset/Barang (Barang Milik Negara) di Kantor Dinas Pekerjaan Umum Provinsi Jambi
}

\author{
Etik Winarni ${ }^{*}$, Yolanda Sari ${ }^{2}$ \\ 1,2 Universitas Muhammadiyah Jambi \\ Correspondence email: *etikwinarni88@gmail.com, yolandasari2711@gmail.com
}

\begin{abstract}
Abstrak. Pengelolaan aset yang baik akan berkontribusi besar bagi pemerintah daerah, sebaliknya jika pengelolaannya buruk maka akan berdampak buruk pula pada pemerintah daerah tersebut. Berdasarakan latar belakang diatas maka peneliti tertarik untuk menganalisa lebih jauh tentang “Analisis Optimalisasi Pengelolaan Aset/Barang (Barang Milik Negara) di Kantor Dinas Pekerjaan Umum Provinsi Jambi Tahun 2017-2018”. Data yang dianalisis menggunakan Uji validitas dan reliabilitas untuk data kuesioner dan analisis Regresi Linear Berganda. Dari hasil analisis hasil analisis dan pembahasan penelitian tentang optimalitas pengelolaan aset (Barang Milik Negara) pada kantor Dinas Pekerjaan Umum dan Perumahan Rakyat Provinsi Jambi yang meliputi perencanaan, pelaksanaan, serta pembinaan, pengawasan, pengendalian,dapat disimpulkan bahwa Hipotesis pertama menyatakan bahwa tidak ada pengaruh yang signifikan antara perencanaan terhadap tingkat optimalitas pengelolaan aset/barang (Barang Milik Negara) pada kantor Dinas Pekerjaan Umum dan Perumahan Rakyat Provinsi Jambi dalam penelitian ini terbukti, karena tidak memiliki pengaruh yang positif dan tidak signifikan.Hipotesis kedua menyatakan bahwa memiliki pengaruh yang signifikan antara pelaksanaan terhadap tingkat optimalitas pengelolaan aset/barang (Barang Milik Negara) pada kantor Dinas Pekerjaan Umum dan Perumahan Rakyat Provinsi Jambi dalam penelitian ini terbukti, karena memiliki pengaruh yang positif dan signifikan. Hipotesis ketiga yang menyatakan bahwa memiliki pengaruh yang positif dan signifikan antara Pembinaan, pengawasan dan pengendalian terhadap tingkat optimalitas pengelolaan aset/barang (Barang Milik Negara) pada kantor Dinas Pekerjaan Umum dan Perumahan Rakyat Provinsi Jambi dalam penelitian ini terbukti, karena memiliki pengaruh yang positif dan signifikan.
\end{abstract}

Kata kunci: Manajemen Aset; Pengelolaan asset

Abstract. Good asset management will contribute greatly to local governments, on the contrary if the management is bad it will also have a negative impact on the local government. Based on the background above, the researcher is interested in further analyzing the "Analysis of Optimizing the Management of Assets / Goods (State Property) in the Office of the Provincial Public Works Office of 2017-2018". Data were analyzed using validity and reliability tests for questionnaire data and Multiple Linear Regression analysis. From the results of the analysis of the results of the analysis and discussion of research on the optimality of asset management (State Property) at the Office of Public Works and Public Housing in Jambi Province which includes planning, implementation, as well as guidance, supervision, control, it can be concluded that the first hypothesis states that there is no influence significant between the planning of the optimal level of management of assets / goods (State Property) in the office of the Public Works and Housing Agency of Jambi Province in this study proved, because it does not have a positive and insignificant effect. The second hypothesis states that it has a significant influence between implementation of the optimal level of management of assets / goods (State Property) in the office of the Public Works and Public Housing Office of Jambi Province in this study is proven, because it has a positive and significant effect. The third hypothesis which states that has a positive and significant influence between the Development, supervision and control of the optimal level of management of assets / goods (State Property) at the Office of Public Works and Public Housing in the Province of Jambi in this study is proven, because it has a positive influence and significant.

Keywords: Asset Management; Asset Management

\section{PENDAHULUAN}

Dalam aset atau barang milik daerah itu sendiri dikelola oleh unit organisasi yang memiliki hak dan tanggung jawab atas aset tersebut. Pengelola barang/aset daerah tersebut adalah pejabat yang berwenang dan bertanggungjawab menetapkan kebijakan dan pedoman serta melakukan pengelolaan barang milik negara/daerah. (Peraturan Pemerintah Nomor 6 Tahun 2006). Pengelolaan aset atau barang milik daerah, pemerintah daerah dituntut untuk mampu secara profesional dan mandiri mengelola asetnya melalui kemampuan manajemen aset yang terbagi dalam lima tahapan kerja, yaitu: inventarisasi aset, legal audit, penilaian aset, optimalisasi pemanfaatan aset serta pengawasan dan pengendalian dengan pengembangan Sistem Informasi Manajemen Aset (SIMA). (Homer, dkk: 2012).

Menghadapi persoalan pengelolaan aset daerah perlu proses yang cukup panjang, pemerintah daerah dituntut untuk bekerja keras dalam pelaksanaannya sehingga tujuan tersebut bisa tercapai. Untuk mencapai hal tersebut tentunya bukan perkara yang mudah, pasalnya banyak hal yang harus diperbaharui dan diperbaiki. Struktur pemerintahan merupakan elemen utama yang harus diperbaiki dan diperbaharui, karena dengan struktur yang baik akan menghasilkan pekerjaan yang baik, begitu pula sebaliknya. Semuanya harus dilihat dari tupoksinya dan harus disesuaikan dengan 
pejabat yang diperlukan, sehingga tidak terjadi pemerintahan yang kaya struktur tapi miskin fungsi, dan tidak juga terjadi sebaliknya kaya fungsi tapi miskin struktur, harus seimbang antara keduanya. Peraturan perundang-undangan tentang pengelolaan asset daerah juga harus dipertegas, selama ini peraturan yang ada hanyalah mengenai teknis pengelolaan dan tidak ada peraturan perundang-undangan yang mengatur tentang hukuman atau punishment kepada pemerintah yang melalaikan tupoksinya. (Sufri Nuryamin: 2015).

Peraturan Pemerintah Nomor 6 Tahun 2006 tentang Pengelolaan Barang Milik Negara/Daerah merupakan acuan utama pemerintah dalam pengelolaan aset daerah, yang juga sesuai dengan Keputusan Menteri Dalam Negeri Nomor 12 Tahun 2003 tentang Pedoman Penilaian Barang Daerah, serta dipertegas dengan Peraturan Menteri Dalam Negeri Nomor 17 Tahun 2007 tentang Pedoman Teknis Pengelolaan Barang Milik Daerah. Aset daerah merupakan suatu potensi ekonomi dan sumber daya yang bersifat mutlak bagi setiap pemerintah daerah. Pengelolaan aset yang baik akan berkontribusi besar bagi pemerintah daerah, sebaliknya jika pengelolaannya buruk maka akan berdampak buruk pula pada pemerintah daerah tersebut. Berdasarakan latar belakang diatas maka peneliti tertarik untuk menganalisa lebih jauh tentang "Analisis Optimalisasi Pengelolaan Aset/Barang (Barang Milik Negara) di Kantor Dinas Pekerjaan Umum dan Perumahan Rakyat (PUPR) Provinsi Jambi Tahun 2017-2018".

\section{METODE}

Pengumpulan data dalam penelitian ini data primer dengan cara observasi, pengisian kuesioner serta wawancara langsung dengan para pejabat dan pegawai tersebut berasal dari Kasubag Umum, dan Pengurus Barang dan pembantu pengurus barang dan data sekunder diperoleh dari Kasubag Umum bagian pengelolaan asset/barang milik Dinas Pekerjaan Umum dan Perumahan Rakyat Provinsi Jambi. Dengan Alat Analisis kuesioner diukur dengan menggunakan skala likert dengan pengujian instrumen Uji validitas dan reliabilitas. Untuk menguji hipotesis penelitian digunakan analisis regresi linier berganda dikarenakan dalam penelitian ini menggunakan variabel bebas (independent) lebih dari satu. Regresi linear berganda digunakan untuk mengetahui pengaruh dari variabel terikat (dependen), terhadap variabel bebas (independen). Rumus analisis regresi berganda sebagai berikut: (Widarjono, 2009: 28-29)

\section{$\mathrm{Y}=\mathrm{B0}+\mathrm{B1X} 1+B 2 \mathrm{X} 2+\beta 3 \mathrm{X} 3+\mathrm{B4X} 4+\mathrm{e}$}

Keterangan:

$\mathrm{Y}=$ Optimalisasi pengelolaan aset tetap $(\operatorname{tanah}$ dan bangunan);

BO = konstanta; $\beta 1, \beta 2, \beta 3, \beta 4=$ koefisien regresi;

$\mathrm{X} 1=$ Perencanaan;

$\mathrm{X} 2=$ Pelaksanaan;

$\mathrm{X} 3=$ pembinaan, pengawasan dan pengendalian

$\mathrm{E}=$ suku kesalahan, berdistribusi normal dengan rata-rata 0 untuk tujuan perhitungan, e diasumsikan 0 .

\section{Koefisien regresi parsial (uji t)}

Uji-t digunakan untuk membuktikan apakah ada pengaruh secara parsial/individual dari masing-masing variabel independen yaitu inventarisasi aset, legal audit aset, penilaian aset, serta pengawasan dan pengendalian aset terhadap variabel dependent optimalisasi aset tetap (tanah dan bangunan). Adapun langkah-langkah dalam $u j i-t$ adalah sebagai berikut (Widarjono, 2009: 65).

1. Merumuskan hipotesis:

$\mathrm{H} 0=\beta 1=0$ (tidak ada pengaruh variabel independent terhadap variabel dependent)

$\mathrm{Ha}=\beta 1 \neq 0$ (ada pengaruh variabel independent terhadap variabel dependent)

2. Keputusan menolak atau menerima $\mathrm{H} 0$ sebagari berikut:

a. Jika nilai t hitung > nilai t kritis maka $\mathrm{H} 0$ tolak atau menerima $\mathrm{Ha}$

b. Jika nilai thitung < nilai $\mathrm{t}$ kritis maka $\mathrm{H} 0$ diterima atau menolak $\mathrm{Ha}$

\section{Koefisien regresi secara menyeluruh (uji F).}

Untuk mengetahui apakah variabel-variabel independent yaitu inventarisasi aset, legal audit aset, penilaian aset, serta pengawasan dan pengendalian aset secara keseluruhan signifikan secara statistik dalam mempengaruhi variabel dependen. Adapun langkahlangkah dalam $u j i-F$ adalah sebagai berikut:

1. Merumuskan hipotesis

$\mathrm{H} 0: B 1=\beta 2=\beta 3=\beta 4=0$ (secara keseluruhan tidak ada pengaruh yang signifikan antara independent variable terhadap dependent variable).

$\mathrm{Ha}$ : selain HO (secara keseluruhan ada pengaruh yang signifikan antara independent variable terhadap dependent variable).

2. Keputusan menolak atau menerima H0 sebagai berikut:

a. Jika F-statistik > F-tabel, maka H0 ditolak, artinya secara keseluruhan independent variabel berpengaruh terhadap dependent variabel.

b. Jika F-statistik < F-tabel, maka H0 diterima, artinya secara keseluruhan independent variabel tidak berpengaruh terhadap dependent variabel

\section{Uji koefisien determinasi (R2)}

Nilai R2 menunjukan sejauh mana hubungan antara variabel dependent dengan variabel independent. Dengan kata lain koefisien determinasi digunakan untuk mengukur seberapa besar proporsi variasi variabel 
dependent dijelaskan oleh semua variabel independent secara bersama-sama (Widarjono, 2009: 66).

\section{Hipotesis}

Hipotesis adalah suatu dugaan sementara yang merupakan harapan yang diinginkan oleh seseorang, sehubung dengan penelitian yang dilakukanya. Adapun hipotesis penelitian ini yaitu:

1. Tidak berpengaruh positif antara Perencanaan dengan tingkat optimalisasi pengelolaan aset/barang (barang milik negara) di Kantor Dinas Pekerjaan Umum dan Perumahan Rakyat di Provinsi Jambi;

2. Terdapat pengaruh positif antara Pelaksanaan dengan tingkat optimalisasi pengelolaan aset/barang (barang milik negara) di Kantor Dinas Pekerjaan Umum dan Perumahan Rakyat di Provinsi Jambi;
3. Terdapat pengaruh positif antara pembinaan, pengawasan dan pengendalian dengan tingkat optimalisasi pengelolaan aset/barang (barang milik negara) di Kantor Dinas Pekerjaan Umum dan Perumahan Rakyat di Provinsi Jambi;

\section{HASIL DAN PEMBAHASAN}

Implementasi Pengelolaan Aset Tetap (Barang Milik Negara) Pada Kantor Dinas Pekerjaan Umum dan Perumahan Rakyat Provinsi Jambi

\section{Jumlah Aset Tetap (Barang Milik Negara)}

Untuk mengetahui lebih jelasnya mengenai jumlah aset tetap (Barang Milik Negara) Pada Kantor Dinas Pekerjaan Umum Kota Pekanbaru maka berikut ini penulis akan menguraikan jumlah aset tetap (Barang Milik Negara), lebih jelasnya dapat dilihat pada tabel berikut ini:

Tabel 1. Daftar Jumlah Aset Tetap (Barang Milik Negara)

\begin{tabular}{|c|c|c|c|}
\hline \multirow{2}{*}{ No } & \multirow{2}{*}{$\begin{array}{c}\text { Nama Aset } \\
\text { (barang milik negara) }\end{array}$} & \multicolumn{2}{|c|}{ Tahun 2018} \\
\hline & & Jumlah Barang (unit) & Harga/nilai (Rp) \\
\hline 1. & TANAH & 80 & \\
\hline \multirow[t]{10}{*}{2.} & PERALATAN DAN MESIN & 4,844 & \\
\hline & a. Alat-alat Besar & & \\
\hline & b. Alat-alat angkutan & & \\
\hline & c.Alat-alat Bengkel dan Alat Ukur & & \\
\hline & d.Alat-alat Pertanian / Peternakan & & \\
\hline & e.Alat-alat Kantor dan Rumah Tangga & & \\
\hline & f.Alat-alat Studio dan komunikasi & & \\
\hline & g.Alat-alat Kedokteran & & \\
\hline & h.Alat-alat Laboratorium & & \\
\hline & i. Alat-alat Keamanan & & \\
\hline \multirow[t]{2}{*}{3.} & GEDUNG DAN BANGUNAN & 38 & \\
\hline & a.Bangunan Gedung & & \\
\hline \multirow[t]{5}{*}{4.} & JALAN,IRIGASI DAN JARINGAN & 5,700 & $5,385,907,376,306.74$ \\
\hline & a.Jalan dan Jembatan & & \\
\hline & b.Bangunan Air/Irigasi & & \\
\hline & c.Instalasi & & \\
\hline & d.Jaringan & & \\
\hline \multirow[t]{5}{*}{5.} & ASET TETAP LAINYA & 1035 & $224,207,851,087.28$ \\
\hline & a. Buku Perpustakaan & & \\
\hline & b. Barang Bercorak Kesenian / Kebudayaan & & \\
\hline & c. Hewan Ternak dan Tumbuhan & & \\
\hline & d. Renovasi & & \\
\hline \multirow[t]{5}{*}{6.} & ASET LAINNYA & 7,665 & \\
\hline & a. Aset tak Berwujud (Software) & & \\
\hline & b. Aset Rusak Berat & & \\
\hline & c. Aset dalam Penguasaan Pihak Lain (Akan di Hibah) & & \\
\hline & d. Piutang Belanja Yang Telah Dibayar & & \\
\hline 7. & KONTRUKSI DALAM PENGERJAAN & 6 & \\
\hline
\end{tabular}

Sumber: Data Olahan Pada Kantor Dinas Pekerjaan Umum dan Perumahan Rakyat Provinsi Periode Juli 2017

\section{Siklus Pengelolaan Aset Tetap Dan Dukumen Sumber (Barang Milik Daerah) Pada Kantor Dinas Pekerjaan Umum}

Dokumen Sumber (barang milik Daerah) pada Kantor Dinas Pekerjaan umum Provinsi Jambi adalah semua berkas penting yang dihasilkan dari siklus pengelolaan aset tersebut maupun berkas penting yang mendasari suatu siklus atau tahapan untuk dilakukan. Dokumen sumber ini diperlukan untuk menjadi bukti dalam proses pengelolaan maupun penyampaian akhir dari suatu hasil pelaporan kekayaan daerah yang mempengaruhi penyajian jumlah dan nilai aset suatu daerah. Daftar dokumen sumber yang menjadi acuan dalam kelengkapan pada penelitian ini tercermin pada 
Peraturan Menteri Dalam Negeri Nomor 19 Tahun 2016 tentang Pedoman Pengelolaan Barang Milik Daerah. Dapat dilihat pada table dibawah ini.

Daftar Dokumen Sumber Pada Siklus Pengelolaan Aset Tetap:

\section{Dokumen Sumber Berdasasrkan Permendagri No. 19 Tahun 2016}

1. Rencana Kebutuhan Barang Milik Daerah

2. Rencana Kebutuhan Pemeliharaan Barang Milik Daerah

3. Daftar Kebutuhan Barang Milik Daerah

4. Daftar Kebutuhan Pemeliharaan Barang Milik Daerah

5. Daftar Barang Pengguna / Daftar Barang Kuasa Pengguna

6. Kartu Inventaris Barang

7. Daftar Barang Milik Daerah
8. Buku Inventaris Dan Buku Induk Inventaris

9. Laporan Barang Semesteran Dan Tahunan

10. Laporan Barang Milik Daerah

11. Surat Perjanian Pinjam Pakai

12. Bukti Kepemilikan Atas Nama Pemerintah Daerah

13. Daftar Hasil Pemeliharaan Barang

14. SK Penghapusan

15. SK Pemindahtanganan

16. SK Status Penggunaan Barang Milik Daerah

Penjelasan di atas, kelengkapan dokumen sumber yang ada pada bidang pengelolaan aset pada kantor Dinas Pekerjaan Umum dan Perumahan Rakyat Provinsi Jambi sesuai hasil wawancara dan beberapa dokumen contoh yang diberikan kepada peneliti dapat dilihat pada Tabel 2 Beserta Keterangannnya.

Tabel 2. Kelengkapan Dokumen Sumber

\begin{tabular}{|c|c|c|c|}
\hline No & Daftar Dokumen & $\begin{array}{l}\operatorname{Ada}(\sqrt{ }) / \\
\text { Tidak }(\mathbf{X})\end{array}$ & Keterangan \\
\hline 1 & Rencana Kebutuhan Barang Milik Daerah & $\sqrt{ }$ & $\begin{array}{l}\text { Disertai contoh dokumen Peraturan Menteri Dalam } \\
\text { Negeri Nomor } 19 \text { Tahun } 2016\end{array}$ \\
\hline 2 & Rencana Kebutuhan Pemeliharaan Barang Milik Daerah & $\sqrt{ }$ & $\begin{array}{l}\text { Disertai contoh dokumen Peraturan Menteri Dalam } \\
\text { Negeri Nomor } 19 \text { Tahun } 2016\end{array}$ \\
\hline 3 & Daftar Kebutuhan Barang Milik Daerah & $\sqrt{ }$ & $\begin{array}{l}\text { Dari RKBMD dihasilkan DPA dan langsung menjadi } \\
\text { DKBMD, tdk diberikan contoh. }\end{array}$ \\
\hline 4 & Daftar Kebutuhan Pemeliharaan Barang Milik Daerah & $\sqrt{ }$ & $\begin{array}{l}\text { Dari RKBMD dihasilkan DPA dan langsung menjadi } \\
\text { DKBMD, tdk diberikan contoh. }\end{array}$ \\
\hline 5 & $\begin{array}{l}\text { Daftar Barang Pengguna / Daftar Barang Kuasa } \\
\text { Pengguna }\end{array}$ & $\sqrt{ }$ & $\begin{array}{l}\text { Disertai contoh dokumen Peraturan Menteri Dalam } \\
\text { Negeri Nomor } 19 \text { Tahun } 2016\end{array}$ \\
\hline 6 & Kartu Inventaris Barang & $\sqrt{ }$ & Diberikan Contoh Dari KIB A-F \\
\hline 7 & Daftar Barang Milik Daerah & $\sqrt{ }$ & Rekapitulasi Diberikan Contoh Dari KIB A-F \\
\hline 8 & Buku Inventaris Dan Buku Induk Inventaris & $\sqrt{ }$ & $\begin{array}{l}\text { Diberikan contoh buku inventaris } \\
\text { dari } 1 \text { unit organisasi }\end{array}$ \\
\hline 9 & Laporan Barang Semesteran Dan Tahunan & $\sqrt{ }$ & Diberikan contoh laporan semesteran dan tahunan \\
\hline 10 & Laporan Barang Milik Daerah & $\sqrt{ }$ & Rekapitulasi LBS dan LBT \\
\hline 11 & Surat Perjanian Pinjam Pakai & $\sqrt{ }$ & $\begin{array}{l}\text { Diberikan contoh surat perjanjian pinjam pakai tanah dan } \\
\text { bangunan. }\end{array}$ \\
\hline 12 & Bukti Kepemilikan Atas Nama Pemerintah Daerah & $\sqrt{ }$ & Diberikan contoh SK dan setifikat tanah \\
\hline 13 & Daftar Hasil Pemeliharaan Barang & $\sqrt{ }$ & Hasil Pemeliharaan gedung kantor \\
\hline 14 & SK Penghapusan & $\sqrt{ }$ & Diberikan Sk penghapusan \\
\hline 15 & SK Pemindahtanganan & $\sqrt{ }$ & Diberikan SK hibah tanah \\
\hline 16 & SK Status Penggunaan Barang Milik Daerah & $\sqrt{ }$ & Diberikan SK Status penggunaan Kendaraan \\
\hline
\end{tabular}

Kelengkapan dokumen sumber tersebut diatas mensyaratkan bahwa Pengelolaan Aset Tetap/Barang Milik Daerah telah sesuai dengan peraturan Menteri Dalam Negeri Nomor 19 Tahun 2016 dari segi administratif. Akan tetapi Pengelolaan aset negara Pasal 1 Ayat (1) dan Ayat (2) PP No. 27 Tahun 2014 adalah tidak sekedar administrative semata, tetapi lebih maju berfikir dalam menangani aset negara, dengan bagaimana meningkatkan efisiensi, efektifitas dan menciptakan nilai tambah dalam mengelola aset. Oleh karena itu, lingkup pengelolaan aset Negara menurut Peraturan Menteri Dalam Negeri Nomor 19 Tahun 2016 tentang Pedoman Teknis Pengelolaan Barang Milik Daerah Pasal 1 Ayat 28, Pengelolaan Barang Milik
Daerah adalah keseluruhan kegiatan yang meliputi perencanaan kebutuhan dan penganggaran, pengadaan, penggunaan, pemanfaatan, pengamanan dan pemeliharaan, penilaian, pemindahtanganan,pemusnahan, penghapusan, penatausahaan dan pembinaan, pengawasan dan pengendalian. (Permendagri nomor 19 tahun 2016) menyatakan siklus pengelolaan aset adalah tahapantahapan yang harus dilalui dalam manajemen pengelolaan aset.

\section{Pengujian instrumen kuesioner}

\section{Validitas}


Etik Winarni dan Yolanda Sari, Analisis Optimalisasi Pengelolaan Aset/Barang (Barang Milik Negara) di Kantor Dinas Pekerjaan Umum Provinsi Jambi

Tabel 3. Hasil Perhitungan Uji Validitas

\begin{tabular}{|c|c|c|c|}
\hline Pernyataan & Corrected Item-Total Correlation & Nilai $r$ table & Keterangan \\
\hline Perencanaan 1 & .422 & 0,351 & Valid \\
\hline Perencanaan 2 & .034 & 0,351 & Tidak Valid \\
\hline Perencanaan 3 & .467 & 0,351 & Valid \\
\hline Perencanaan 4 & .187 & 0,351 & Tidak Valid \\
\hline Perencanaan 5 & .661 & 0,351 & Valid \\
\hline Perencanaan 6 & .667 & 0,351 & Valid \\
\hline Perencanaan 7 & .401 & 0,351 & Valid \\
\hline Pelaksanaan 1 & .002 & 0,351 & Tidak Valid \\
\hline Pelaksanaan 2 & .772 & 0,351 & Valid \\
\hline Pelaksanaan 3 & .400 & 0,351 & Valid \\
\hline Pelaksanaan 4 & .636 & 0,351 & Valid \\
\hline Pelaksanaan 5 & .683 & 0,351 & Valid \\
\hline Pelaksanaan 6 & .676 & 0,351 & Valid \\
\hline Pelaksanaan 7 & .272 & 0,351 & Tidak Valid \\
\hline Pelaksanaan 8 & .535 & 0,351 & Valid \\
\hline Pelaksanaan 9 & .787 & 0,351 & Valid \\
\hline Pelaksanaan 10 & .790 & 0,351 & Valid \\
\hline Pelaksanaan 11 & .828 & 0,351 & Valid \\
\hline Pelaksanaan 12 & .863 & 0,351 & Valid \\
\hline Pelaksanaan 13 & .829 & 0,351 & Valid \\
\hline Pelaksanaan 14 & .769 & 0,351 & Valid \\
\hline Pembinaan 1 & .586 & 0,351 & Valid \\
\hline Pembinaan 2 & .756 & 0,351 & Valid \\
\hline Pembinaan 3 & .638 & 0,351 & Valid \\
\hline Pembinaan 4 & .547 & 0,351 & Valid \\
\hline Pembinaan 5 & .689 & 0,351 & Valid \\
\hline Pembinaan 6 & .759 & 0,351 & Valid \\
\hline Pembinaan 7 & .758 & 0,351 & Valid \\
\hline Pembinaan 8 & .949 & 0,351 & Valid \\
\hline Pembinaan 9 & .847 & 0,351 & Valid \\
\hline Pembinaan 10 & .625 & 0,351 & Valid \\
\hline Pengelolaan Aset 1 & .841 & 0,351 & Valid \\
\hline Pengelolaan Aset 2 & .686 & 0,351 & Valid \\
\hline Pengelolaan Aset 3 & .825 & 0,351 & Valid \\
\hline Pengelolaan Aset 4 & .792 & 0,351 & Valid \\
\hline Pengelolaan Aset 5 & .464 & 0,351 & Valid \\
\hline Pengelolaan Aset 6 & .470 & 0,351 & Valid \\
\hline Pengelolaan Aset 7 & .881 & 0,351 & Valid \\
\hline Pengelolaan Aset 8 & .824 & 0,351 & Valid \\
\hline Pengelolaan Aset 9 & .533 & 0,351 & Valid \\
\hline Pengelolaan Aset 10 & .527 & 0,351 & Valid \\
\hline Pengelolaan Aset 11 & .444 & 0,351 & Valid \\
\hline Pengelolaan Aset 12 & .891 & 0,351 & Valid \\
\hline Pengelolaan Aset 13 & .771 & 0,351 & Valid \\
\hline Pengelolaan Aset 14 & .880 & 0,351 & Valid \\
\hline
\end{tabular}


Hasil uji validitas terhadap jawaban kuesioner ini menunjukan bahwa 4 item pertanyaan dalam kuesioner dinyatakan tidak valid. Hal ini karena item memiliki koefisien corrected item total correlation yang lebih besar daripada nilai kritis koefisien korelasi dapat dilihat pada tabel $\mathrm{r}$ product moment dengan derajat signifikansi 5 persen. Dengan sampel sebanyak 23 responden, maka didapat nilai kritis koefisien korelasinya sebesar 0,351 . Tabel 3 menunjukan bahwa semua item (butir) pernyataan dinyatakan valid. Pernyataan dinyatakan valid karena memiliki $r$ hitung $=r$ tabel $(0,351)$.

\section{Reliabilitas}

Uji reabilitas ini digunakan untuk menunjukan sejauh mana hasil pengukuran mampu menghasilkan data yang reliable (relative sama) apabila alat ukur tersebut digunakan berulang-ulang terhadap objek yang sama (Nunnally,1994). Dengan bantuan program SPSS 17.0 for windows diperoleh hasil bahwa semua pertanyaan variabel (variabel perencanaan, pelaksanaan, pembinaan pengawasan pengendalian, serta pengelolaan aset) reliable karena memiliki nilai cronbach alpha Based on Standardized items nilai tersebut $0,970>\mathrm{R}$ tabel 0,351 yang berarti tes keseluruhan Reliabel. (lihat Ghozali, 2012: 48). Hasilnya adalah sebagai berikut.

Tabel 4. Reliability Statistics

\begin{tabular}{|r|r|r|r|}
\hline \multicolumn{2}{|c|}{ Cronbach's Alpha } & Cronbach's Alpha Based on Standardized Items & N of Items \\
\hline .966 & .970 & 45 \\
\hline
\end{tabular}

\section{Hasil Regresi}

Dengan menggunakan bantuan komputer pada program SPSS diperoleh hasil-hasil pengujian sebagai berikut:

Tabel 5. Hasil Analisis Regresi Berganda:

Coefficients $^{\mathrm{a}}$

\begin{tabular}{|c|c|c|c|c|c|}
\hline \multirow[b]{2}{*}{ Model } & \multicolumn{2}{|c|}{ Unstandardized Coefficients } & \multirow{2}{*}{$\frac{\text { Standardized Coefficients }}{\text { Beta }}$} & \multirow[b]{2}{*}{$\mathrm{t}$} & \multirow[b]{2}{*}{ Sig. } \\
\hline & B & Std. Error & & & \\
\hline 1 (Constant) & -1.976 & .780 & & -2.533 & .020 \\
\hline Pelaksanaan & .925 & .166 & .80 & 5.572 & .000 \\
\hline Perencanaan & -.017 & .211 & -.01 & -.080 & .937 \\
\hline $\begin{array}{l}\text { Pembinaan,pengawasan dan } \\
\text { pengendalian }\end{array}$ & .555 & .156 & .31 & 3.563 & .002 \\
\hline
\end{tabular}

a. Dependent Variable: Optimalisasi Pengelolaan asset

Berdasarkan hasil perhitungan pada Tabel 5 dapat dibuat persamaan regresi berganda untuk melihat pengaruh optimalisasi pengelolaan asset/barang Aset (Barang Milik Negara) pada Kantor Dinas Pekerjaan Umum Provinsi Jambi

\section{$Y=-1.976+0,925 X 1+-0.017 X 2+0,555 X 3$}

\section{Koefisien regresi parsial (uji $t$ ).}

Pengujian ini bertujuan untuk menguji signifikan hubungan antara variabel X (independen) dan variabel Y (dependen), atau menguji apakah variabel-variabel independen yaitu perencanaan (X1), pelaksanaan (X2), serta pembinaan, pengawasan, pengendalian(X3), berpengaruh secara individu/parsial terhadap tingkat optimalitas pengelolaan asset kantor Dinas Pekerjaan Umum dan Perumahan Rakyat Provinsi Jambi. Uji t dilakukan dengan membandingkan nilai t- statistik hasil perhitungan masing-masing variabel bebas terhadap nilai ttabel. Ketentuan dalam uji $\mathrm{t}$ adalah jika nilai t hitung > nilai $\mathrm{t}$ kritis maka $\mathrm{H} 0$ ditolak atau menerima $\mathrm{Ha}$, sebaliknya jika nilai $\mathrm{t}$ hitung < nilai t kritis maka $\mathrm{HO}$ diterima atau menolak Ha. Dengan menggunakan SPSS 17.0 diperoleh hasil sebagai berikut. 
Etik Winarni dan Yolanda Sari, Analisis Optimalisasi Pengelolaan Aset/Barang (Barang Milik Negara) di Kantor Dinas Pekerjaan Umum Provinsi Jambi

Tabel 6. Uji Signifikan Parameter Individual (Uji Statistik t) Coefficients $^{\mathbf{a}}$

\begin{tabular}{|l|r|r|r|r|}
\hline & & & \multicolumn{2}{|c|}{ Standardized } \\
Coefficients
\end{tabular}

a. Dependent Variable: Optimalisasi Pengelolaan asset (Y)

Dari hasil uji statistis t terlihat bahwa koefisien variabel bebas (independen) dengan menggunakan unstadardized koefisien dari ke empat variabel independen yang dimasukan ke dalam model regresi pada tingkat kepercayaan 95 persen, variabel pelaksanaan, pembinaan pengawasan pengendalian berpengaruh signifikan terhadap tingkat optimalisasi pengelolaan aset, sementara variabel perencanaan tidak signifikan mempengarui optimalitas pengelolaan aset.

\section{Uji statistik F (F-test)}

Pengujian ini bertujuan untuk mengetahui apakah perencanaan, pelaksanaan, serta pembinaan, pengawasan, pengendalian secara serentak/bersamasama mempunyai pengaruh yang signifikan terhadap optimalisasi pengelolaan aset. Ketentuan dalam uji $\mathrm{F}$ adalah jika F-statistik > F-tabel, maka H0 ditolak, artinya secara keseluruhan independent variable berpengaruh terhadap dependent variable, sebaliknya jika F-statistik < F-tabel, maka H0 diterima, artinya secara keseluruhan independent variable tidak berpengaruh terhadap dependent variable. Hasil uji $\mathrm{F}$ dapat ditampilkan pada tabel sebagai berikut.

Tabel 7. Uji Signifikansi Simultan (Uji Statistik F)

\begin{tabular}{|c|c|c|c|c|c|c|}
\hline \multicolumn{7}{|c|}{ ANOVA $^{\text {b }}$} \\
\hline & & Sum of Squares & Df & Mean Square & $\mathrm{F}$ & Sig. \\
\hline \multirow[t]{3}{*}{1} & Regression & 6.566 & 3 & \multirow{3}{*}{$\begin{array}{r}2.189 \\
.054\end{array}$} & \multirow[t]{3}{*}{40.287} & \multirow[t]{3}{*}{$.000^{\circ}$} \\
\hline & Residual & 1.032 & 19 & & & \\
\hline & Total & 7.598 & 22 & & & \\
\hline
\end{tabular}

a. Predictors: (Constant), Pembinaan, pengawasan dan pengendalian, Perencanaan, Pelaksanaan

b. Dependent Variable: Optimalisasi Pengelolaan Asset

Dari hasil Uji ANOVA atau F test didapat nilai F hitung sebesar 40.287dengan probabilitas 0,000. F tabel sebesar 3,49 dengan $\mathrm{a}=5$ persen. Dengan demikian $\mathrm{F}$ hitung lebih besar dari $\mathrm{F}$ tabel atau dengan kata lain H0 ditolak dan menerima $\mathrm{Ha}$, dapat disimpulkan bahwa semua variabel independen yaitu perencanaan, pelaksanaan, serta pembinaan, pengawasan, pengendalian secara bersama-sama mempengaruhi variabel dependen yaitu optimalitas pengelolaan aset.

\section{Koefisien determinasi (R2)}

Koefisien determinasi menyatakan berapa besar proporsi variasi variabel dependen dapat dijelaskan oleh variabel independen.

Tabel 8. Koefisien Determinasi

\begin{tabular}{|c|c|c|c|c|c|}
\hline \multirow{2}{*}{ Model } & $\mathrm{R}$ & \multirow{2}{*}{ R Square } & Adjusted R Square & Std. Error of the Estimate & Durbin-Watson \\
\hline 1 & $.930^{\mathrm{a}}$ & .864 & .843 & .23307 & 2.349 \\
\hline
\end{tabular}

a. Predictors: (Constant), Pembinaan, pengawasan dan pengendalian, Perencanaan, Pelaksanaan

b. Dependent Variable: Optimalisasi Pengelolaan asset 
Dari tampilan output SPSS model summary dapat dilihat besarnya R-squared $=0,864$ yang berarti bahwa 86,4 persen variasi variabel optimalitas pengelolaan aset dapat dijelaskan oleh variasi dari ke empat variabel independen perencanaan, pelaksanaan, serta pembinaan, pengawasan, pengendalian, sedangkan sisanya 13,6 persen dijelaskan oleh variabel lain diluar model.

\section{SIMPULAN}

Berdasarkan hasil analisis dan pembahasan penelitian tentang optimalitas pengelolaan asset/barang (Barang Milik Negara) pada kantor Dinas Pekerjaan Umum dan Perumahan Rakyat Provinsi Jambi yang meliputi perencanaan, pelaksanaan, serta pembinaan, pengawasan, pengendalian dapat disimpulkan bahwa:

1. Hipotesis pertama menyatakan bahwa tidak ada pengaruh yang signifikan antara perencanaan terhadap tingkat optimalitas pengelolaan aset/barang (Barang Milik Negara) pada kantor Dinas Pekerjaan Umum dan Perumahan Rakyat Provinsi Jambi dalam penelitian ini terbukti, karena tidak memiliki pengaruh yang positif dan tidak signifikan.

2. Hipotesis kedua menyatakan bahwa memiliki pengaruh yang signifikan antara pelaksanaan terhadap tingkat optimalitas pengelolaan aset/barang (Barang Milik Negara) pada kantor Dinas Pekerjaan Umum dan Perumahan Rakyat Provinsi Jambi dalam penelitian ini terbukti, karena memiliki pengaruh yang positif dan signifikan.

3. Hipotesis ketiga yang menyatakan bahwa memiliki pengaruh yang positif dan signifikan antara Pembinaan, pengawasan dan pengendalian terhadap tingkat optimalitas pengelolaan aset/barang (Barang Milik Negara) pada kantor Dinas Pekerjaan Umum dan Perumahan Rakyat Provinsi Jambi dalam penelitian ini terbukti, karena memiliki pengaruh yang positif dan signifikan.

\section{DAFTAR PUSTAKA}

Eselon IV Lembaga Administrasi Negara. Diktat Teknis. 2007. Manajemen Aset Daerah (Asset Management Pyscal). Hlm. 2

Faustino Cardoso Gomes. 2000. Manajemen Sumber Daya Manusia, Yogyakarta: Andi Offset hlm.1

Hasfi, Nyemas, Martoyo dan Dwi Haryono. Pengelolaan Barang Milik Daerah di DPKAD Kab. Sintang Tahun2013. Jurnal Tesis PMIS-UNTAN-PSIAN2013. Hlm 2

Homer, Yonas, and Wahyu Widayat. Inventarisasi Dan Legalisasi Aset Tetap Tanah Dan Bangunan Milik Pemerintah Daerah Provinsi Papua Di Kota Jayapura Tahun 2012. Diss. Universitas Gadjah Mada, 2014. Hlm2.
Jimung, Martin. 2005. Politik Lokal dan Pemerintah Daerah dalam Prespektif Otonomi Daerah. Yogyakarta: Yayasan Pustaka Nusatama.

Peraturan Daerah Kabupaten Bantul No. 30 Tahun 2008 Tentang Pengelolaan Barang Milik Daerah.

Peraturan Pemerintah Republik Indonesia Nomor 6 Tahun 2006 Tentang Pengelolaan Barang Milik Negara/Daerah.

Sufri Nuryamin,2015. Pengelolaan Aset/Barang Milik Daerah Di Dinas Pekerjaan Umum Kabupaten Bantul Tahun 2014-2015. Jurusan Ilmu Pemerintahan. Universitas Muhammadiyah. Yogyakarta.

Siregar, Doli. D, 2004, Management Aset Strategi Penataan Konsep Pembangunan Berkelanjutan secara Nasional dalam Konteks Kepala Daerah sebagai CEO's pada Era Globalisasi dan Otonomi Daerah, penerbit PT Gramedia Pustaka Utama, Jakarta.

Sekaran, Uma, 2006, "Metode Penelitian Untuk Bisnis". Salemba Empat. Jakarta.

Singarimbun, Masri dan Effendi, Sofyan. 1989. "Metode Penelitian Survey, Edisi satu”, PT Pustaka LP3ES, Jakarta.

Undang-Undang Republik Indonesia Nomor 32 Tahun 2004 Tentang Pemerintahan Daerah

-------, Undang-Undang Nomor 6 Tahun 2006 tentang Pengelolaan Barang Milik Negara/Daerah , Undang-Undang Nomor 32 Tahun 2004 tentang Pemerintahan Daerah

-, Undang-Undang Nomor 33 Tahun 2004 tentang Perimbangan Keuangan Antara Pemerintah Pusat dan Daerah

-------, Peraturan Menteri Dalam Negeri Nomor 17 Tahun 2007 tentang Pedoman Teknis Pengelolaan Barang Milik Daerah

Widarjono, Agus, 2009, Ekonometrika Pengantar dan Aplikasinya, Ekonisia, Yogyakarta. 